\title{
Restoration of Thickening Growth of Radishes by Application of SADH at Higher Temperatures
}

\author{
Shigetoshi Suzuki and Taikichi Takano \\ College of Agriculture, Meijo University, Tempaku, Nagoya 468
}

\begin{abstract}
Summary
Thickening growth of radishes (Raphanus sativus L. cv. Rapid Red) is disturbed by comparatively high temperatures above optimum range. In this paper, the possibility to obtain sufficiently thickened radishes at high temperature of $20-25^{\circ} \mathrm{C}$ (night-day) was examined by the utilization of a growth retardant (SADH).

By the application of SADH to radishes grown at higher temperatures, the hypocotyl elongation and leaf growth were reduced, whereas the thickening growth of hypocotyl and fleshy root was stimulated. In other words, sufficiently thickened and normally shaped radishes were produced even at higher temperatures above optimum range by the application of SADH.
\end{abstract}

\section{Introduction}

Several growth retardants are used in horticulture, especially in cases where small and compact plants are required. Many other effects of growth retardants on developmental processes in plants have been shown experimentally (2), so that further utilization of growth retardants in horticulture will be expected.

Radishes require a comparatively low temperature range for their growth. At relatively high temperatures, therefore, radish growth was disturbed; hypocotyl elongation was markedly stimulated, foliage leaves became larger in weight as compared with hypocotyl and roots, and thickening growth was reduced (8). Cathey and Piringer (4) reported that the stems of garden annuals such as Petunia were lengthened at high night temperature or in the long daylength, and the application of phosfon to these plants resulted in the restoration of elongation to the normal level. These results suggest a potential utilization of growth retardants to produce the desired thickness of radishes at higher temperatures.

Since SADH (Succinic Acid 2,2-Trimethylhydrazide) has a relatvely wide spectrum of plant response and is effective on radishes(3), it was utilized in this experiment to examine

Received for publication September 1, 1977. its effect on the growth of radishes at high temperatures.

\section{Materials and Methods}

Seeds of radishes (Raphanus sativus L. cv. Rapid Red)were sterilized with $0.1 \%$ Uspulun for $30 \mathrm{~min}$, before being washed in running tap water for $2 \mathrm{hr}$. They were germinated on a wet filter paper in the dark at $25^{\circ} \mathrm{C}$ for 24 hr. Germinated seeds were selected for uniformity and planted in black plastic pots filled with vermiculite. They were grown in the phytotron of Nagoya University where temperature was controlled at $20-25^{\circ} \mathrm{C}$ (night -day)above optimum range or $13-18^{\circ} \mathrm{C}$ within optimum range for radish growth. Three days after germination, the aqueous solutions of $\mathrm{SADH}$ at concentrations of 0,2000 , and 4000 $\mathrm{mg} / l$ were applied as foliar sprays with a hand sprayer until the foliage leaves were completely wet. Such treatment was repeated weekly for 4 weeks. Plants were watered daily with a nutrient solution ( $1 \mathrm{~g} / l$ Hyponex). Twenty plants were used in one treatment.

\section{Results}

By higher temeratures, radish growth was markedly influenced; the growth of foliage leaves and elongationh of ypocotyl were stimulated, and thickening of hypocotyl was reduced (Fig. 1). These effects of higher 


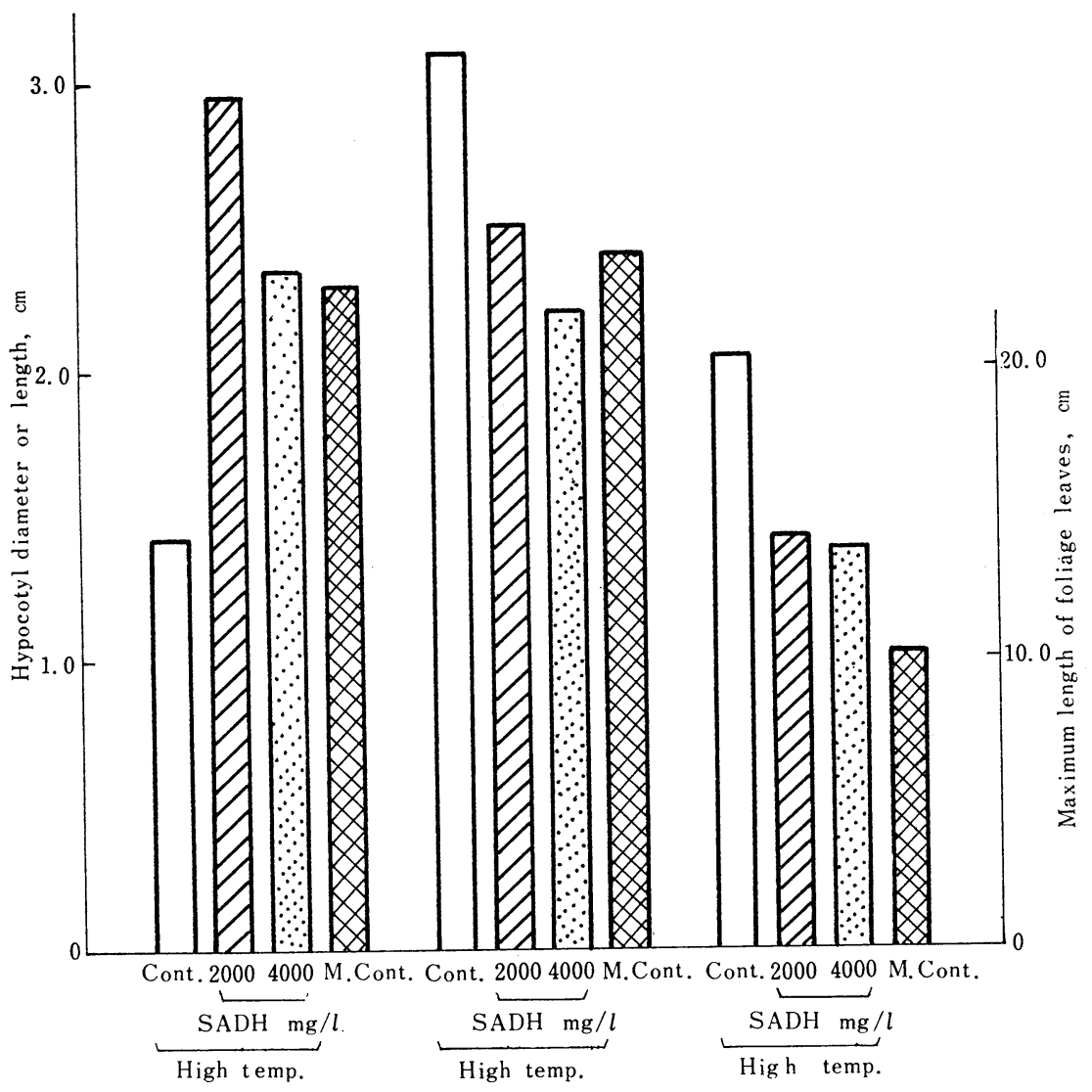

Fig. 1. Effect of SADH on hypocotyl diameter (left), hypocotyl length (middle), and maximum length of foliage leaves (right) in radish plants grown at higher temperatures $\left(20-25^{\circ} \mathrm{C}\right.$, night-day). M. Cont., control plants grown at $13-18^{\circ} \mathrm{C}$.

temperature were antagonized by $\mathrm{SADH}$ treatment. In the SADH treated plants grown at higher temperatures, the thickening of hypocotyl was stimulated and, elongation of hypocotyl and growth of foliage leaves were reduced.

Dry weight growth was also affected by the SADH application (Fig.2). Total dry weight decreased in the plants treated with $4000 \mathrm{mg} / \mathrm{l}$ of SADH. That of foliage leaves was decreased by the two treatments of 2000 and 4000 $\mathrm{mg} / l$ of $\mathrm{SADH}$. In hypocotyl, the increace in dry weight was caused by its application, especially by $2000 \mathrm{mg} / \mathrm{l} \mathrm{SADH}$ application. Dry weight of roots was less affected. Consequently, the ratio of the dry weight of each organ to the total dry weight was influenced by the SADH application (Fig. 3). In the control plants at higher temperature, the ratio of leaves was $58.3 \%$ and that of hypocotyl
$32.7 \%$. Following the application of $\mathrm{SADH}$, however, the former decreased and the latter increased to the normal level obtained in the plants grown at $13-18^{\circ} \mathrm{C}$.

\section{Discussion}

In the preceding study (8), one of the authors showed the effect of higher temperatures on the growth of radish plants and suggested the possibility to obtain adequately thickened and normally shaped radishes, even at higher temperatures, by the utilization of grow th retardants. By the higher temperature, hypocotyl elongation was stimulated, distribution of dry matter to foliage leaves was enhanced, and thickening growth of hypocotyl was lowered (8).

Reduction in plant height is the most pronounced effect of growth retardants. In petunia plants, stem elongation was stimulated. 


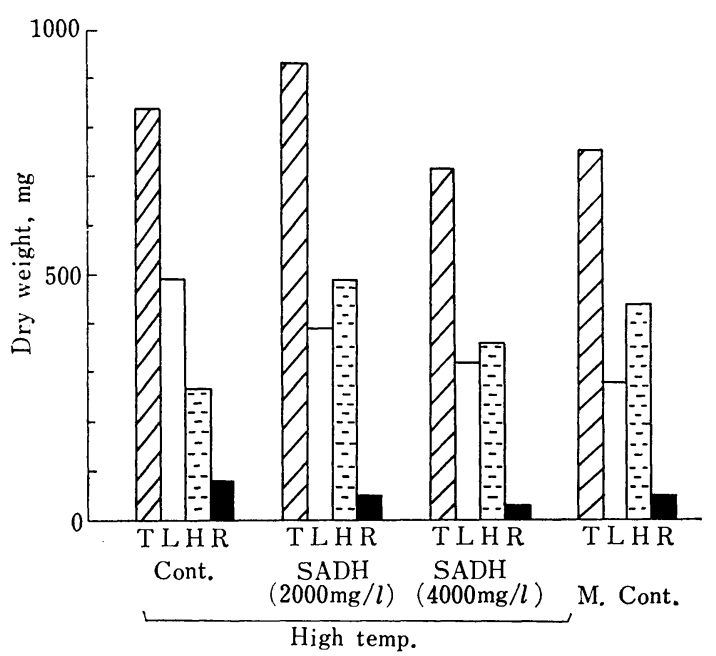

Fig. 2. Effect of SADH on dry weight of a whole plant $(T)$, leaves (L), hypocotyls $(H)$, and roots (R) in radish plants grown at higher temperatures (20- $25^{\circ} \mathrm{C}$, night-day). M. Cont., control plants grown at $13-18^{\circ} \mathrm{C}$.

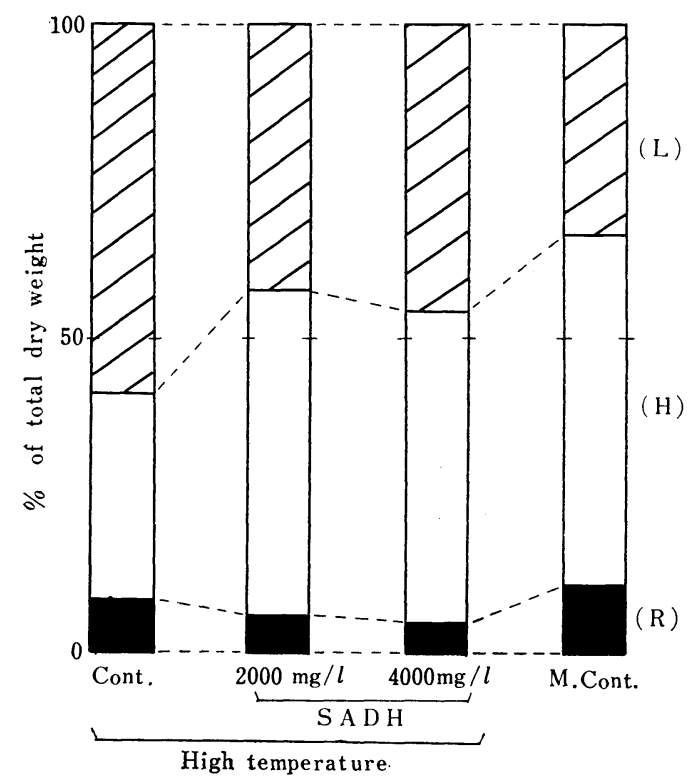

Fig. 3. Effect of SADH on relative dry weight of leaves (L), hypacotyls $(H)$, and roots (R) in radish plants grown at higher temperatures (20$25^{\circ} \mathrm{C}$, night-day). Relative dry weight is represented as $\%$ of total dry weight. M. Cont., control plants grown at $13-18^{\circ} \mathrm{C}$.

at higher night temperatures, being partially recovered to the normal level by the application of phosfon(4). In radish plants, likewise, elongation of hypocotyl and leaves at higher temperatures was reduced by $\mathrm{SADH}$ application (Fig. 2). Although the mode of action of $\mathrm{SADH}$ in retarding the stem elongation is not fully understood (10), the retarding effect of $\mathrm{SADH}$ seems to be greater at higher temperatures rather than at temperatures favorable for radish growth. Since thickening growth was not accelerated in radishes, in which hypocotyl elongation was stimulated by the higher temperatures (8), the retarding effect of SADH on hypocotyl elongation might be considered as one of the factors restoring the thickening growth at higher temperatures.

Although a species of plants has its own pattern of dry matter distribution, the pattern varies with environmental conditions; in radish plants, the apportionment of dry matter to leaves was enhanced at higher temperatures (Fig. 3). By SADH application, however, distribution pattern in the plants grown at higher temperatures was shifted to the normal pattern observed in the control plants grown at 13$18^{\circ} \mathrm{C}$. In radish cv. Cherrybelle, SADH reduced leaf fresh weight, increased root fresh weight, and therefore increased root/leaf ratio (1). Similar results were obtained also in carrots (5) and tomato plants (11) applied with SADH and CCC, respectively. Although the mechanism of action of $\mathrm{SADH}$ on dry matter apportioning is not clarified, it is interesting to us that the normal distribution pattern can be restored by $\mathrm{SADH}$ application in radishes grown at higher temperatures.

Although the stimulation of thickening growth expressed as increase in root diameter by $\mathrm{SADH}$ application was not shown in the report of Boe et al. (1), our results showed that the increase in hypocotyl diameter was caused by SADH application (Fig.2). As shown in the studies on apple plants (6), their stem radius increased, because cell division and expansion of parenchymatous cells in the pith and cortex were stimulated by the application of SADH. In the review by Cathey (2), the cell division of cambium is described to be stimulated but the development of xylem to be strongly inhibited in Amo-1618 treated bean stems. From preliminary studies of thickened parts in radishes, the formation of meristematic islands derived from active xylem 
parenchymatous cells was observed to be stimulated in hypocotyl of radishes treated with SADH. Because the activity of xylem parenchymatous cells is one of factors causing the active thickening growth, the thickening growth through the activation of division of xylem parenchymatous cells might be stimulated by SADH. Further studies are now in progress.

Temperature is the most important factor influencing the cambial activity. Reduction in cambial activity at higher temperatures is, however, considered to be partly due to an indirect effect; shortage of available water and sugars, hormone content and/or hormonal imbalance due to high temperature may be involved in this phenomenon. According to Loomis and Torrey (7), and Takano (9), auxins, cytokinins, and sugars play important roles in thickening growth of radish roots. It would appear that auxin-cytokinin balance is disturbed at higher temperatures but can be recovered by SADH application. Furthermore, stimulation of dry matter distribution to hypocotyl by SADH application may be one of the factors enhancing hypocotyl thickening. Since plants treated with growth retardants show a marked increase in resistance to various environmental stresses (2), it seems valuable to study utilization of growth retardants for cultivation of plants under unfavorable conditions. This report could be an example of such studies.

\section{Acknowledgement}

We express our thanks to the Laboratory of Horticulture, Faculty of Agriculture, Nagoya University for allowing us to use the phytotron.

\section{Literature Cited}

1. BOE, A. A., T. S. LEE, D. D. TAPIO, and T. J. BANKO. 1973. Effect of SADH on radish. HortScience 8 : 497-498.
2. Cathey, H. M. 1964. Physiology of growth retarding chemicals. Ann. Rev. Plant Physiol. $15: 271-302$.

3. 1975. Comparative plant growthretarding activities of ancymidol with $\mathrm{ACPC}$, phosfon, chlormequat, and $\mathrm{SADH}$ on ornamental plant species. Hort Science. 10 : 204216.

4. - and A. A. PIRINGER. 1961. Relation of phosfon to photoperiod, kind of supplemental light, and night temperature on growth and flowering of garden annuals. Proc.

Amer. Soc. Hort. Sci. 77 : 608-619.

5. Dyson, P. W. 1972. Effect of cycocel (2chloroethyl-trimethyl ammonium chloride) and Alar (N-dimethylamino succinic acid) on the yield of carrots. J. Hort. Sci. $47: 215-$ 220.

6. HAlfaCre, R. G, and J. A. BARDEN. 1968. Anatomical responses of apple leaf and stem tissues to Succinic Acid 2,2-dimethylhydrazide (Alar). J. Amer. Soc. Hort. Sci. 93 : $25-32$.

7. Loomis, R. S. and J. G. Torrey. 1964. Chemical control of vascular cambium initiation in isolated radish roots. Proc. Natl. Acad. Sci. $52: 3-11$.

8. SUZUKI, S. 1978. Growth of radishes as influenced by the high temperatures above the optimum range. J. Japan. Soc. Hort. Sci. $47: 375-381$.

9. TAKANO, T. 1965. Studies on the pithiness of radish. II. The effect of naphthaleneacetic acid, sucrose and boron on the prevention of pithy tissue formation in radish root. J. Japan. Soc. Hort. Sci. 34 : 315-320. (In Japanese).

10. WAKHLOO, J. L. 1976. Hormonal regulation of hypocotyl elongation in Lactuca sativa L. J. Expt. Bot. $26: 841-852$.

11. Wittwer, S. H. and N.E. Tolbert. 1960. (2-chloroethyl) trimethyl ammonium chloride and related compounds as plant growth substances. IV. Effect on growth and flowering of the tomato. Amer. J. Bot. $47: 560-565$. 
高温条件下で育てられたハッカダイコンの生長におよぼす SADH の影響

鈴木茂敏・高野泰吉

(名城大学農学部)

摘 要

高温条件はハッカダイコンの下肧軸伸長および本葉の 生長を促進し，下胚軸部の肥大を著しく抑制する．乙か し, SADH (2000 および $40 \mathrm{c} 0 \mathrm{mg} / l)$ 処理によって，下 胚軸伸長特よび本葉の生長は抑制され，下胚軸の乾物重
は增加し、下胚軸部の肥大は正常な水準に回復した。し たがって，SADHはハッカダイコンの生長に対する高温 ストレスに薬剤治療 (chemical cure)として利用できる 可能性が考兄られた. 